\title{
Hubungan antara Rasio Kadar Kolesterol Total terhadap High Density Lipoprotein (HDL) dengan Kejadian Sindrom Koroner Akut di RSUP Prof. Dr. R. D. Kandou Manado
}

\author{
${ }^{1}$ Mercilia F. Wenas \\ ${ }^{2}$ Edmond L. Jim \\ ${ }^{2}$ Agnes L. Panda
}

\author{
${ }^{1}$ Program Studi Pendidikan Dokter Fakultas Kedokteran Universitas Sam Ratulangi Manado \\ ${ }^{2}$ Bagian Ilmu Penyakit Jantung dan Pembuluh Darah Fakultas Kedokteran \\ Universitas Sam Ratulangi Manado \\ Email: mercilia.wenas@gmail.com
}

\begin{abstract}
From year to year, heart disease cases show an increase as the leading cause of death in the world. Acute coronary syndrome (ACS) is a set of manifestations or symptoms caused by a disturbance in the coronary artery. Blood cholesterol level is one of the major risk factors underlying ACS. High total cholesterol and low high density lipoprotein (HDL) levels will increase the ratio of both and are directly related to increased coronary heart disease. The ratio can be obtained by dividing total cholesterol level with HDL level. This study was aimed to obtain the correlation between ratio of total cholesterol to (HDL) with the incidence of ACS at Prof. Dr. R. D. Kandou Hospital Manado. This was a descriptive analytical study with a retrospective cross sectional design using medical record data. Data were analyzed by using the chi-square test. There were 117 patients obtained by using total sampling technique. The chi-square test showed a $P$ value of $0.026(P<0,05)$. Conclusion: There was a significant correlation between the ratio of total cholesterol to HDL and the incidence of ACS.
\end{abstract}

Keywords: acute coronary syndrome, ratio of total cholesterol to HDL.

\begin{abstract}
Abstrak: Kasus penyakit jantung dari tahun ke tahun menunjukkan adanya peningkatan sebagai penyebab kematian tertinggi di dunia. Sindrom koroner akut (SKA) merupakan sekumpulan manifestasi atau gejala akibat gangguan pada arteri koronaria. Kadar kolesterol darah merupakan faktor risiko utama proses aterosklerosis yang mendasari terjadinya sindrom koroner akut. Kadar kolesterol total yang tinggi dan HDL yang rendah akan meningkatkan rasio dari keduanya dan berhubungan langsung dengan peningkatan risiko penyakit jantung koroner. Rasio dapat diperoleh dengan cara membagi kadar kolesterol total dengan HDL. Penelitian ini bertujuan untuk mengetahui hubungan antara rasio kadar kolestrol total terhadap high density lipoprotein (HDL) dengan kejadian SKA di RSUP Prof. Dr. R. D. Kandou Manado. Jenis penelitian ialah deskriptif analitik dengan desain potong lintang dan retrospektif menggunakan data rekam medis pasien. Data dianalisis dengan uji chi-square. Jumlah sampel penelitian sebanyak 117 pasien diperoleh dengan teknik total sampling. Hasil uji chi-square menunjukkan nilai $P=0,026(P<0,05)$. Simpulan: Terdapat hubungan bermakna antara rasio kadar kolesterol total terhadap HDL dengan kejadian SKA.
\end{abstract}

Kata kunci: rasio kadar kolesterol total terhadap HDL, sindrom koroner akut

Dari tahun ke tahun kasus penyakit jantung menunjukkan adanya peningkatan sebagai penyebab kematian tertinggi di dunia. Menurut WHO, $12,8 \%$ dari 7.254 .000 kematian di seluruh dunia disebabkan oleh sindrom koroner akut (SKA) pada tahun 2008. Di Amerika Serikat setiap tahun 550.000 orang meninggal karena penyakit 
ini. Di Indonesia, SKA juga masih di anggap sebagai penyumbang angka kematian tertinggi, dengan prevalensi nasional penyakit jantung di Indonesia sebesar 7,2\% (berdasarkan diagnosis tenaga kesehatan dan gejala) sedangkan prevalensi di Sulawesi Utara sebesar $8,2 \% .^{1,2}$

Sindrom koroner akut merupakan sekumpulan manifestasi atau gejala akibat gangguan pada arteri koronaria. Sindrom koroner akut mencakup penyakit jantung koroner yang bervariasi karena gejala awal serta manajemen awal sering serupa mulai dari angina pektoris tidak stabil dan infark miokard tanpa ST-elevasi sampai infark miokard dengan ST-elevasi. ${ }^{3,4}$

Faktor risiko SKA dapat dibagi dua, yaitu: faktor risiko yang dapat dimodifikasi atau bisa diubah (modifiable), termasuk hipertensi, kadar kolesterol, merokok, obesitas, diabetes melitus, aktivitas fisik dan stres sedangkan faktor risiko seperti usia, jenis kelamin, ras, dan riwayat penyakit keluarga ialah yang tidak dapat dimodifikasi. ${ }^{5,6}$

Kadar kolesterol darah merupakan faktor risiko utama proses aterosklerosis yang mendasari terjadinya penyakit jantung koroner (PJK) termasuk SKA. Aterosklerosis adalah kelainan yang ditandai dengan peradangan pembuluh darah yang merupakan pusat dari semua tahap aterosklerosis. Sindrom koroner akut secara nyata dipengaruhi oleh konsentrasi, komposisi lipid dan lipoprotein dalam plasma yaitu peningkatan kadar kolesterol total, LDL, dan trigliserida, sedangkan kadar HDL menurun. ${ }^{7}$ Bila kadar kolesterol total lebih dari $200 \mathrm{mg} / \mathrm{dL}$ dan $\mathrm{HDL} \leq 40 \mathrm{mg} / \mathrm{dL}$ maka hal tersebut menunjukan adanya dislipidemia. Kadar kolesterol total yang tinggi dan HDL yang rendah akan meningkatkan rasio dari keduanya dan berhubungan langsung dengan peningkatan risiko penyakit jantung koroner (PJK) termasuk sindrom koroner akut. ${ }^{8-10}$

Menurut American Heart Association $(\mathrm{AHA})^{11}$ rasio kolesterol total terhadap kolesterol high density lipoprotein (HDL) atau disebut juga Cardiac Risk Ratio merupakan angka perbandingan antara kadar kolesterol total dengan kadar HDL yang bisa digunakan untuk mendeteksi dini resiko terkena PJK.

Penelitian ini bertujuan untuk mengetahui hubungan antara rasio kadar kolestrol total terhadap HDL dengan kejadian SKA di RSUP Prof. Dr. R. D. Kandou Manado. Diharapkan penelitian ini dapat menambah wawasan dan memberikan informasi serta dapat menjadi bahan masukkan mengenai hubungan rasio kadar kolesterol total terhadap HDL dengan kejadian SKA.

\section{METODE PENELITIAN}

Jenis penelitian ini ialah deskriptif analitik dengan desain potong lintang retrospektif. Pengambilan data sekunder berupa rekam medis pasien SKA di RSUP Prof. Dr. R. D. Kandou Manado. Teknik pengambilan sampel menggunakan total sampling, dimana pengam-bilan sampel dilakukan pada seluruh penderita SKA yang memiliki rekam medis kolesterol total dan HDL di CVBC RSUP Prof. Dr. R. D. Kandou Manado selama Januari-Desember 2016.

Data diolah berdasarkan variabel penelitian dan disajikan dalam bentuk diagram dan tabel. Uji data menggunakan uji chi-square.

\section{HASIL PENELITIAN}

Berdasarkan penelitian yang dilakukan secara retrospektif di CBVC RSUP Prof. Dr. R. D. Kandou Manado periode JanuariDesember 2016, dari database ditemukan 259 pasien SKA; terdapat 117 orang pasien sesuai dengan kriteria inklusi.

Dari 117 pasien SKA terdapat 82 orang dengan jenis kelamin laki-laki dan 35 orang dengan jenis kelamin perempuan (Gambar 1). Terdapat 18 orang berusia 3549 tahun, 40 orang berusia 50-59 tahun, dan 59 orang berusia $\geq 60$ tahun (Gambar 2). Dari keseluruhan sampel, terdapat 12 orang dengan unstable angina pectoris (UAP), 55 dengan Non ST-Elevetion Myocardial Infarction (NSTEMI), dan 50 dengan ST-Elevetion Myocardial Infarction (STEMI) (Gambar 3). 


\section{Jenis Kelamin}

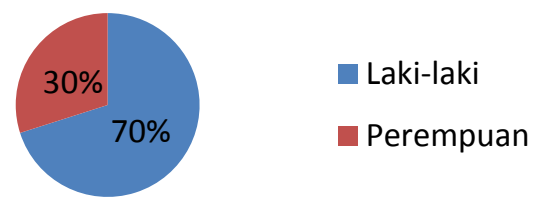

Gambar 1 Distribusi pasien SKA berdasarkan jenis kelamin.

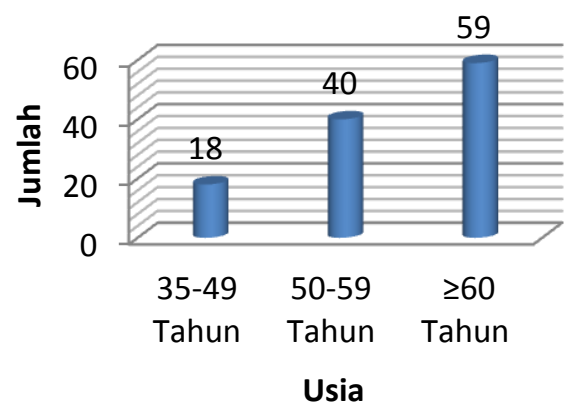

Gambar 2 Disribusi pasien SKA berdasarkan usia

\section{Jumlah Penderita SKA}

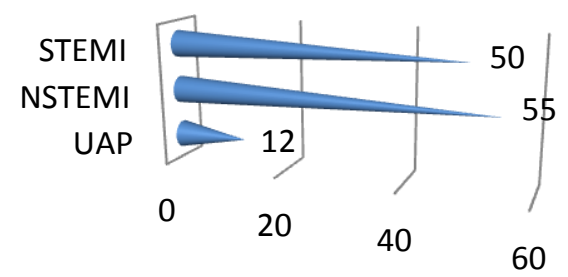

Gambar 3 Distribusi pasien berdasarkan diagnosis

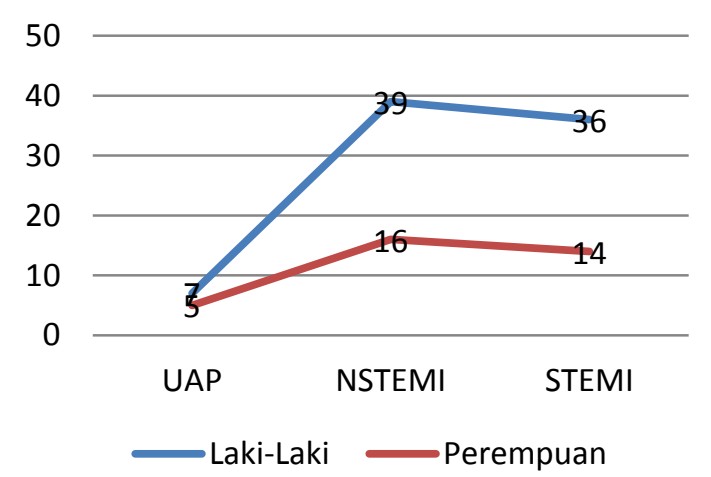

Gambar 4 Distribusi jenis kelamin berdasarkan diagnosis
Dari hasil penelitian didapatkan 7 orang berjenis kelamin laki-laki dan 5 orang berjenis kelamin perempuan yang menderita UAP. Untuk penderita NSTEMI terdapat 39 orang laki-laki dan 16 orang perempuan. Terdapat 36 orang laki-laki menderita STEMI dan sisanya yaitu 14 orang berjenis kelamin perempuan (Gambar 4).

Berdasarkan hasil kolesterol total, dari 117 rekam medik pasien SKA didapatkan 81 orang dalam batas normal $(<200$ $\mathrm{mg} / \mathrm{dl}), 24$ orang dalam batas hati-hati (200 - $240 \mathrm{mg} / \mathrm{dl}$ ) dan 12 orang dalam batas bahaya (>240 mg/dl) (Tabel 1).

Tabel 1. Distribusi sampel penelitian berdasarkan kadar kolesterol total

\begin{tabular}{ccc}
\hline $\begin{array}{c}\text { Kadar kolesterol } \\
\text { total }(\mathbf{m g} / \mathbf{d l})\end{array}$ & Jumlah & Persentase \\
\hline Normal $(<200)$ & 81 & $69,2 \%$ \\
Hati-hati $(200-240)$ & 24 & $20,5 \%$ \\
Bahaya $(>240)$ & 12 & $10,3 \%$ \\
Total & 117 & $100 \%$ \\
\hline
\end{tabular}

Dari hasil kadar HDL yang terdapat dalam rekam medik 117 pasien SKA didapatkan 12 orang dalam batas normal (>45 mg/dl), 42 orang dalam batas hatihati $(35-45 \mathrm{mg} / \mathrm{dl})$, dan 63 orang dalam batas berbahaya $(<35 \mathrm{mg} / \mathrm{dl})$.

Tabel 2. Distribusi sampel penelitian berdasarkan kadar HDL

\begin{tabular}{ccc}
\hline $\begin{array}{c}\text { Kadar HDL } \\
(\mathbf{m g} / \mathbf{d l})\end{array}$ & Jumlah & Persentase \\
\hline Normal $(>45)$ & 12 & $10,3 \%$ \\
Hati-hati $(35-45)$ & 42 & $35,9 \%$ \\
Bahaya $(<35)$ & 63 & $53,8 \%$ \\
Total & 117 & $100 \%$ \\
\hline
\end{tabular}

Dari 117 sampel terdapat 18 orang yang memiliki rasio normal dan 99 orang yang memiliki rasio tinggi (Tabel 3).

Dari total 117 sampel yang dianalisis menggunakan uji chi-square, antara rasio kolesterol total dan HDL dengan kejadian SKA didapatkan nilai $P=0,026(P<0,05)$. 
Tabel 3 Hasil cross tabulation rasio-SKA

\begin{tabular}{ccccc}
\hline \multirow{2}{*}{ Rasio } & \multicolumn{3}{c}{ SKA } & \\
\cline { 2 - 4 } & UAP & NSTEMI & STEMI & Total \\
\hline Normal & 5 & 6 & 7 & 18 \\
Tinggi & 7 & 49 & 43 & 99 \\
Total & 12 & 55 & 50 & 117 \\
\hline
\end{tabular}

\section{BAHASAN}

Pada penelitian ini terdapat 117 penderita SKA yang terdiri atas 82 pasien berjenis kelamin laki-laki dan 35 pasien berjenis kelamin perempuan (Gambar 1) yang menunjukkan bahwa laki-laki mempunyai risiko lebih besar menderita SKA dibandingkan dengan perempuan. Hal ini sesuai dengan penelitian yang dilakukan oleh Tumade et al. ${ }^{12}$ yang mendapatkan bahwa penderita laki-laki (90 orang) lebih banyak dibandingkan perempuan (36 orang) pada tahun 2014 di RSUP Prof. Dr. R. D. Kandou Manado.

Pada penelitian ini pasien SKA terbanyak berada pada rentang usia 60 tahun ke atas (Gambar 2). Hal ini sesuai dengan penelitian Roth et al. ${ }^{13}$ yang menyatakan bahwa pasien PJK dalam hal ini SKA memiliki frekuensi terbesar pada usia di atas 60 tahun. Proses degeneratif dan meningkatnya paparan agen berbahaya yaitu kolesterol, serta proses terjadinya aterosklerosis berperan penting seiring dengan bertambahnya usia. ${ }^{14}$

Pada penelitian ini ditemukan 117 penderita SKA yang memiliki data pemeriksaan laboratorium kolesterol total dan HDL yang dirawat di RSUP Prof. Dr. R. D. Kandou Manado pada periode Januari-Desember 2016. Terdapat penderita UAP 12 orang, penderita NSTEMI 55 orang, dan penderita STEMI 50 orang (Gambar 3). Hal ini tidak sejalan dengan penelitian dari Torry et al. ${ }^{15}$ yang menyatakan bahwa penderita terbanyak ialah STEMI. Terjadinya perbedaan jumlah pasien di setiap spektrum SKA diakibatkan oleh perbedaan tempat dan waktu penelitian.

Pasien SKA yang memiliki kolesterol total dalam batas normal berjumlah 81 orang, jauh lebih banyak dibanding pasien yang memiliki kolesterol total dalam batas hati-hati yakni 24 orang dan dalam batas bahaya yakni 12 orang (Tabel 1). Hasil yang selaras juga didapatkan dari penelitian Nadeem et al. ${ }^{8}$ yang menyatakan bahwa respon-den yang memiliki peningkatan kolesterol hanya tercatat pada $33 \%$ pasien saja. Walaupun pasien SKA memiliki nilai kolesterol total normal akan tetap menjadi berisiko tinggi jika kadar HDL didapatkan di bawah dari kadar normal karena rasio antara kolesterol total terhadap HDL meningkat. Umumnya pada pasien SKA tanpa peningkatan nilai kolesterol total sering ditandai dengan nilai HDL yang rendah.

Terdapat 42 pasien SKA yang memiliki HDL dalam batas hati-hati dan 63 orang dalam batas bahaya sedangkan yang memiliki HDL dalam batas normal sebanyak 12 orang (Tabel 2). Hal ini sesuai dengan penelitian yang dilakukan oleh Supriyono $^{16}$ yang menyatakan bahwa penderita SKA dengan HDL yang tinggi lebih sedikit dibandingkan penderita SKA dengan HDL yang rendah. HDL dan kolesterol total tidak bisa dinilai sendirisendiri hanya berdasar dari klasifikasi tinggi atau normalnya. Keduanya harus diketahui untuk mendapatkan nilai rasio. Menurut Felix-Redondo ${ }^{17}$ pengaruh penurunan kadar HDL pada risiko koroner lebih besar daripada peningkatan kadar kolesterol total.

Rasio antara kolesterol total terhadap HDL pada subjek penelitian (pasien SKA) sebagian besar tinggi yaitu sebanyak 99 orang dan hanya 18 orang yang memiliki rasio normal (Tabel 3). Rasio antara kolesterol total terhadap HDL diperoleh dari data rekam medis pasien. Kriteria data rasio total kolesterol terhadap HDL dibedakan menjadi normal dan tinggi antara lakilaki dan perempuan. Rasio normal pada laki-laki yakni $\leq 4,5$; dan tinggi jika $>4,5$, sedangkan untuk perempuan rasio normalnya $\leq 4,0$ dan tinggi jika $>4,0 .^{18}$

Hasil analisis rasio kadar kolesterol total terhadap HDL menggunakan SPSS versi 17 for windows dengan uji chi-square menunjukan bahwa nilai $P=0,026(P$ 
$<0,05)$ yang menunjukkan adanya hubungan antara rasio kadar kolesterol total terhadap HDL pada pasien SKA. Hasil ini selaras dengan penelitian Millan et al. ${ }^{18}$ yang mendapatkan bahwa dari berbagai konsentrasi kolesterol, rasio kolesterol total terhadap HDL menjadi salah satu prediktor kuat untuk perkiraan resiko penyakit kardio-vaskular.

\section{SIMPULAN}

Dari hasil penelitian yang dilakukan di RSUP Prof. Dr. R D. Kandou Manado, dapat disimpulkan bahwa terdapat hubungan bermakna antara rasio kolesterol total terhadap HDL dengan kejadian Sindrom Koroner Akut.

\section{SARAN}

Peningkatan kejadian SKA dari tahuntahun sebelumnya menjadi hal penting untuk menilai dan mengevaluasi faktorfaktor risiko. Disarankan untuk meneliti hubungan faktor risiko lain dengan kejadian SKA. Hal tersebut akan memungkinkan dalam merumuskan kebijakan untuk memromosikan gaya hidup sehat serta penilaian resiko awal dan strategi pencegahan tertentu.

\section{DAFTAR PUSTAKA}

1. World Health Organization. 2017. Cardiovascular sisease (CVDs). [cited 2017 Aug 2]. Available from: http://www.who.int/mediacentre/factsh eets/fs317/en/

2. Hasil Riset Kesehatan Dasar (Riskesdas) 2013. Jakarta; Badan Penelitian dan Pengembangan Kesehatan Kementrian RI, 2013.

3. Shiel WC, Stoppler MC. Webster's New World ${ }^{\mathrm{TM}}$ Medical Dictionary (3rd ed). New Jersey: Wiley Publishing, 2008.

4. Ramrakha P, Hill J. Oxford Handbook of Cardiology: Coronary Artery Disease ( 1st ed). Oxford: Oxford University Press, 2006.

5. Grundy SM, Pasternak R, Greenland P, Smith S, Fuster V. Assessment of cardiovascular risk by use of multiplerisk-factor assessment equations. Circulation. 1999;100:1481-92.
6. Burazerl G, Goda A, Sulo G, Stefa J, Roshi E, Kark J. Conventional risk factors and acute coronary syndrome during a period of sosioeconomic transition: population-based case-control study in Tirana, Albania. Croat Med J. 2007; 48:225-33.

7. Balci B. The modification of serum lipids after acute coronary syndrome and importance in clinical practice. Curr Cardiol Rev. 2011;7(4):272-6.

8. Nadeem M, Ahmed SS, Farooq S. Risk factors for coronary heart disease in patients below 45 years of age. Pak J Med Sci. 2013;29(1):91-6.

9. Soeharto I. Kolesterol dan Lemak Jahat Kolesterol, Lemak baik dan Proses Terjadinya Serangan Jantung dan Stroke (Cetakan kedua). Jakarta: PT Gramedia Pustaka Utama, 2002.

10. Ingelsson E, Schaefer EJ, Contois JH, McNamara JR, Sullivan L, et al. Clinical utility of different lipid measures for prediction of coronary heart disease in men and women. JAMA. 2007;298 (7):776-85.

11. American Heart Association. What your cholesterol levels mean. 2017. [cited 2017 Aug 18]. Available from: http://www.heart.org/HEARTORG/En cyclopedia/Heart-Encyclopedia_UCM_ 445084_ContentIndex.jsp?title=cholest erol\%20ratio.

12. Tumade B, Jim EL, Joseph VFF. Prevalensi sindrom koroner akut di RSUP Prof. Dr. R. D. Kandou periode 1 Januari 2014 - 31 Desember 2014. eCl. 2016;4(1):225-26.

13. Roth GA, Fihn SD, Mokdad AH, Aekplakorn W, Hasegawa T, Lim SS. High total serum cholesterol, medication coverage and therapeutic control: an analysis of national health examination survey data from eight countries. Bull WHO. 2010;89:92-101.

14. Torry SRV, Panda AL, Ongkowijaya J. Gambaran faktor resiko penderita sindrom koroner akut yang dirawat di RSU Bethesda Tomohon periode 1 Januari-31 Desember 2012. eBm. 2014;2:4.

15. Woodward M, Barzi F, Feigin V, Gu D, Huxley R, Nakamura $K$, et al. Associations between high-density lipoprotein cholesterol and both stroke 
and coronary heart disease in the Asia Pacific region. Eur Heart J. 2007;28: 2653-60.

16. Supriyono M. Faktor-faktor resiko yang berpengaruh terhadap kejadian penyakit jantung koroner pada kelompok usia $<45$ tahun [Skripsi\}. Semarang: FK-UNDIP; 2008.

17. Félix-Redondo FJ, Grau M, Fernández-
Bergés
D. Cholesterol
and

cardiovascular disease in the elderly. Facts and gaps. Aging and Disease. 2013;4(3):154-69.

18. Millán J, Pintó $X$, Muñoz A, Zúñiga $M$, Rubiés-Prat J, Pallardo LF, et al. Lipoprotein ratios: Physiological significance and clinical usefulness in cardiovascular prevention. Vasc Health Risk Manag. 2009;5:757-65. 